\title{
Comparison of membrane bioreactor systems in wastewater treatment
}

\author{
W. S. Guo, S. Vigneswaran, H. H. Ngo and W. Xing \\ * Faculty of Engineering, University of Technology, Sydney, PO Box 123, Broadway, NSW 2007, Australia \\ (E-mail:wguo@uts.edu.au; s.vigneswaran@uts.edu.au; h.ngo@uts.edu.au;wen.xing@eng.uts.edu.au)
}

\begin{abstract}
This study investigated the performance of four different membrane bioreactor (MBR) systems, namely floating media biofilter-crossflow microfiltration (FMB-CFMF) system, submerged membrane bioreactor (SMBR) alone, submerged membrane adsorption bioreactor (SMABR) and sponge-SMBR system, in terms of critical flux. The results indicated that FMB could be used as a pretreatment unit prior to MBR in order to minimize membrane fouling when the FMB-CFMF system operates under sub-critical flux condition. The addition of powdered activated carbon (PAC) could maintain the sustainable flux at a lower TMP value $(7.5 \mathrm{kPa})$. However, irreversible fouling occurred when the filtration flux exceeded critical flux. The addition of $10 \%$ volume (reactor volume) fraction of sponge could increase sustainable flux of SMBR system to 2 times.
\end{abstract}

Keywords

Submerged membrane bioreactor; critical flux; polyurethane sponge; transmembrane pressure; floating media biofilter

\section{INTRODUCTION}

Among the membrane processes, membrane bioreactor (MBR) technology is becoming a promising option for wastewater treatment and reuse. MBR associates a suspended growth bioreactor and a filtration on porous membrane, which leads to the total retention of biomass (high microbial concentration) and improved biological reactor operation (high sludge ages) in the bioreactor (Lee et al., 2003). The advantages of MBR over conventional activated sludge (AS) are well documented, which include superior organics removal, enhanced nutrient removal stability, lower sludge production, smaller footprint, effluent disinfection and high loading grate capabilities (Stephenson at al., 2000). In the design of MBR systems, the submerged membrane bioreactor (SMBR) can assist in significantly reducing power consumption compared to external loop mode.

Filtration flux stability is a significant component for application and evaluation of any pressuredriven membrane process because one of the major drawbacks limiting the application of membranes in water and wastewater treatment is the reduction of permeate flux with time. The occurrence of fouling affects the performance of the membrane either by deposition of a layer onto the membrane surface which introduces additional resistance to permeate flow, or by blockage or partial blockage of the pores which changes the effective pore size distribution (Field et al., 1995). To overcome membrane fouling problem, a number of studies have been conducted to understand and minimize membrane clogging and the concept of the critical flux is one of them. This concept has been introduced in the mid 1990's with theoretical and experimental evidence.

The critical flux hypothesis for microfiltration (MF) is that on start-up there exists a flux below which a decline of flux with time does not occur; above it fouling is observed (Field et al., 1995). The value of critical flux depends on the hydrodynamics and also on the particle size and their surface and chemical characteristics (Kwon et al., 2000). For crossflow MF (CFMF), two different methods are used to determine the critical flux: (i) Based on particle mass balance: By monitoring the change of particle concentration in the fluid phase, the extent and rate of particle deposition at 
membrane surfaces can be determined at various permeation rates. The highest flux value at which no particle deposition is observed, is taken as the critical flux; (ii) Based on the increase in transmembrane pressure (TMP) required to maintain a constant permeate flux: The TMP increases during the constant permeate flux operation in order to compensate the increase in the resistance to permeation. Accordingly, the critical flux is the flux below which there is no presence of this increase in resistance to permeation (i.e. the TMP is constant with time). In the case of SMBR, 'sub-critical' flux operation does not appear to be feasible and the challenge is determination of the 'sustainable flux', where transmembrane pressure (TMP) rise is tolerable before rapid fouling and increase of TMP is seen to occur (Fane and Leslie, 2004).

In this study, four different configurations of MBR systems were evaluated and their relative merits were assessed in terms of critical flux. The four systems studied were floating media biofilterCFMF (FMB-CFMF) system, SMBR alone, submerged membrane adsorption bioreactor (SMABR) and sponge-SMBR system.

\section{EXPERIMENTAL}

The experiments were conducted using a synthetic wastewater to avoid any fluctuation in the feed concentration and provide a continuous source of completely biodegradable organic pollutants. The synthetic wastewater has total organic carbon (TOC) concentration of 120-130 mg/L and COD of 320-350 mg/L. The composition of synthetic waster is given in Table 1 (Lee et al., 2003). $\mathrm{NaHCO}_{3}$ or $\mathrm{H}_{2} \mathrm{SO}_{4}$ were added to the wastewater to maintain a constant $\mathrm{pH}$ around 7.

Table 1 Constituents of the Synthetic Wastewater

\begin{tabular}{lcc}
\hline Compounds & $\begin{array}{c}\text { Molecular weight } \\
(\mathrm{g} / \mathrm{mol})\end{array}$ & $\begin{array}{c}\text { Concentration } \\
(\mathrm{mg} / \mathrm{L})\end{array}$ \\
\hline Organics and nutrients & & \\
$\quad$ Glucose $\left(\mathrm{C}_{6} \mathrm{H}_{12} \mathrm{O}_{6}\right)$ & 180.0 & 280 \\
Ammonium sulfate $\left(\left(\mathrm{NH}_{4}\right)_{2} \mathrm{SO}_{4}\right)$ & 132.1 & 72 \\
Potassium phosphate $\left(\mathrm{KH}_{2} \mathrm{PO}_{4}\right)$ & 136.1 & 13.2 \\
Trace nutrients & & \\
Calcium chloride $\left(\mathrm{CaCl}_{2} \cdot 2 \mathrm{H}_{2} \mathrm{O}\right)$ & 147.0 & 0.368 \\
Magnesium sulfate $\left(\mathrm{MgSO}_{4} \cdot 7 \mathrm{H}_{2} \mathrm{O}\right)$ & 246.5 & 5.07 \\
Manganese chloride $\left(\mathrm{MnCl}_{2} \cdot 4 \mathrm{H}_{2} \mathrm{O}\right)$ & 197.9 & 0.275 \\
Zinc sulfate $\left(\mathrm{ZnSO} \cdot 7 \mathrm{H}_{2} \mathrm{O}\right)$ & 287.5 & 0.44 \\
Ferric chloride anhydrous $\left(\mathrm{FeCl}_{3}\right)$ & 162.2 & 1.45 \\
Cupric sulfate $\left(\mathrm{CuSO}_{4} \cdot 5 \mathrm{H}_{2} \mathrm{O}\right)$ & 249.7 & 0.391 \\
Cobalt chloride $\left(\mathrm{CoCl}_{2} \cdot 6 \mathrm{H}_{2} \mathrm{O}\right)$ & 237.9 & 0.42 \\
Sodium molybdate dihydrate $\left(\mathrm{Na}_{2} \mathrm{MoO}_{4} \cdot 2 \mathrm{H}_{2} \mathrm{O}\right)$ & 242.0 & 1.26 \\
Yeast extract & & 30 \\
\hline
\end{tabular}

The schematic diagram of the first configuration of FMB-CFMF used in this study is shown in Figure 1. The total membrane area of the flat-sheet CFMF was $3.24 \times 10^{-3} \mathrm{~m}^{2}$. The solution was circulated along the surface of the flat-plate membrane in the module at various crossflow velocities. PVDF (modified polyvinylidene difluoride) Minitan-S Microporous membranes (with pore size of $0.45 \mu \mathrm{m}$ ) were used. New membrane was used in each experiment to obtain reproducible results. The synthetic wastewater was delivered from a stock tank to the CFMF cell. The reject water and filtered water were returned to the feed tank. The initial transmembrane 
pressure was controlled by two valves and its variation during the filtration was monitored by using a pressure transducer at three points $\mathrm{P} 1, \mathrm{P} 2$ and Pf respectively. The TMP was calculated using the following equation: $\mathrm{TMP}=(\mathrm{P} 1+\mathrm{P} 2) / 2-\mathrm{Pf}$

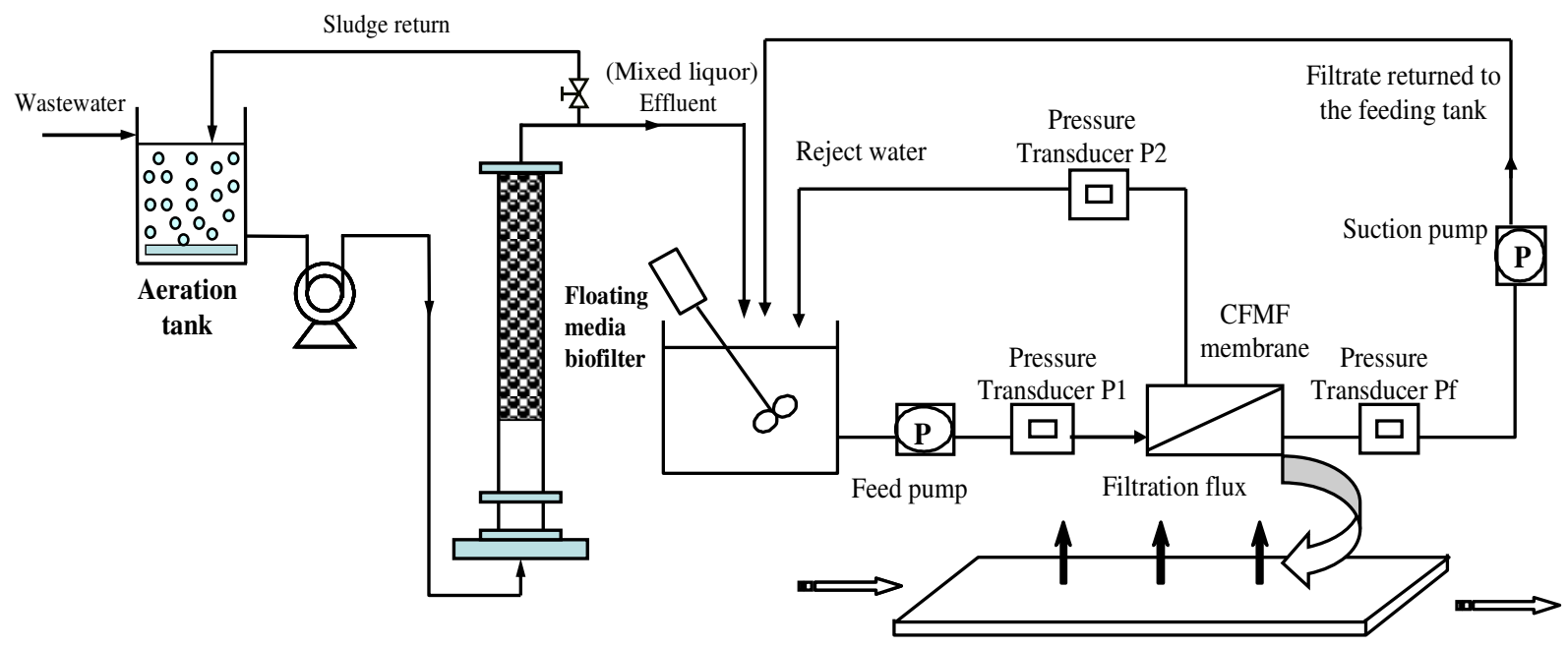

Figure 1 Critical flux experimental set-up of FMB-CFMF

The second and third configurations are SMBR and SMABR. Both SMBR and SMABR were filled with sludge and acclimatized to synthetic wastewater for 12 days. In SMABR system, a predetermined amount of powdered activated carbon (PAC) $(5 \mathrm{~g} / \mathrm{L})$ was added into the reactor at the beginning of the acclimatization to adsorb the dissolved organic substances. The PAC (80\% min finer than 75 micron) used was wood based with surface area of $882 \mathrm{~m}^{2} / \mathrm{g}$ and mean pore diameter $30.61 \AA$. There was no further addition PAC during the experimental period. A polyethylene hollow fiber membrane module was used with the pore size of $0.1 \mu \mathrm{m}$ and surface area of $0.195 \mathrm{~m}^{2}$. The schematic diagram of the submerged hollow fiber microfiltration system is shown in Figure 2. For physical cleaning, filtrate backwash was used every 1 hour for 1 min duration at a backwash rate of $30 \mathrm{~L} / \mathrm{m}^{2} . \mathrm{h}$.

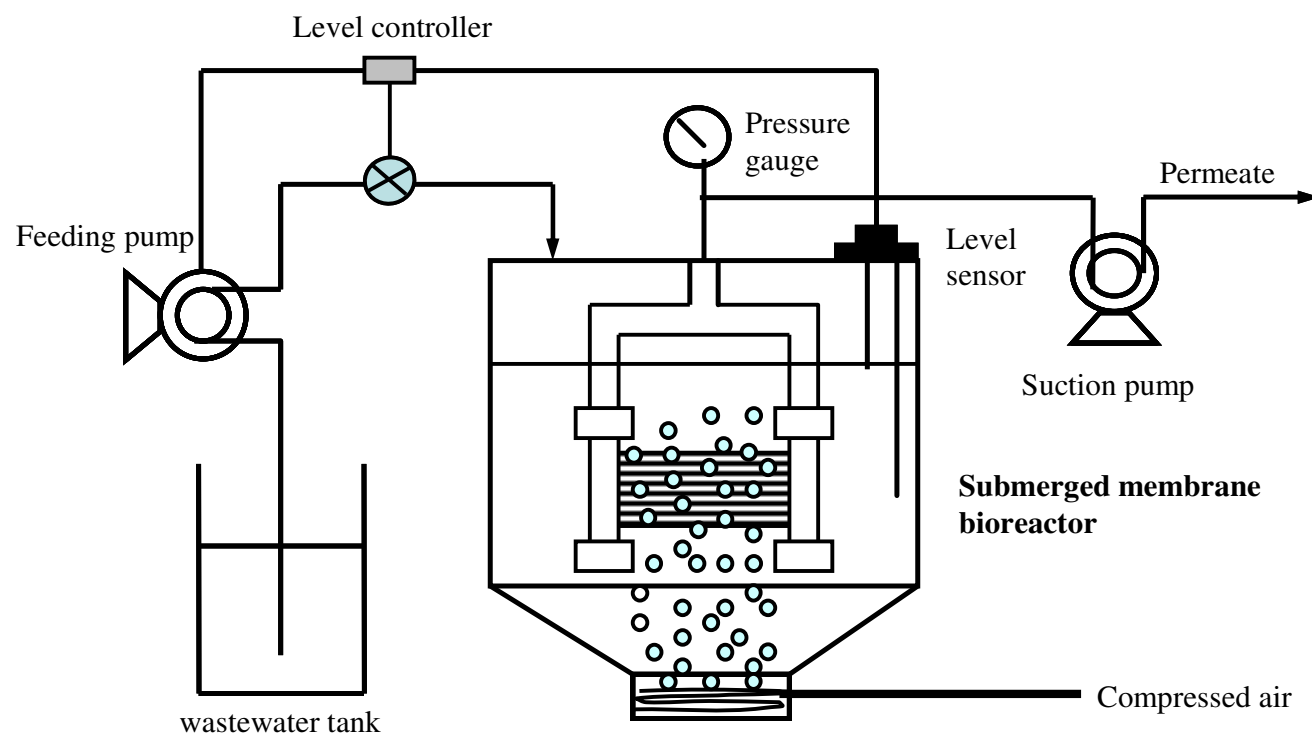

Figure 2 Experimental set-up of SMBR 
In the fourth MBR configuration, the reticulated porous polyester-polyurethane sponge (PPS) was used in sponge-SMBR system. The PPS has density of $28-30 \mathrm{~kg} / \mathrm{m}^{3}$ with cell count of 45 cells $/ \mathrm{in}^{2}$. The dimensions of the sponge cubes are $10 \mathrm{~cm}, 10 \mathrm{~cm}$ and $10 \mathrm{~cm}$ in length, width and thickness respectively. Before running the sustainable flux tests, the sponge cubes were also acclimatized to synthetic wastewater.

\section{RESULTS AND DISCUSSION}

\section{Membrane fouling study of FMB-CFMF system}

The acclimatized mixed liquor from the floating media biofilter (FMB) was directed to the crossflow microfiltration (CFMF) and membrane fouling was investigated under different operating conditions. The FMB system was operated at a filtration rate of $1 \mathrm{~m} / \mathrm{h}$. Experiments were carried out at different cross flow velocity to study its effect on development of transmembrane pressure (TMP) (Figure 6). The Reynolds number and shear stress calculated for different crossflow velocity together with the TMP increases are listed in Table 2 (Guo et al., 2007).

Table 2 The Reynolds number (Re) and shear stress values for different crossflow velocities

\begin{tabular}{ccccc}
\hline $\begin{array}{c}\text { Crossflow } \\
\text { velocity }(\mathrm{m} / \mathrm{s})\end{array}$ & $\begin{array}{c}\text { Flow rate } \\
\left(\mathrm{L} / \mathrm{m}^{2} . \mathrm{h}\right)\end{array}$ & Reynolds number & $\begin{array}{c}\text { Shear stress } \\
(\mathrm{pa})\end{array}$ & $\begin{array}{c}\text { TMP increase in } \\
5 \text { hours }(\mathrm{kPa})\end{array}$ \\
0.15 & 3240 & 120 & 2.97 & 36.0 \\
0.30 & 6481 & 240 & 5.94 & 22.6 \\
0.45 & 9722 & 360 & 8.91 & 17.4 \\
0.60 & 12962 & 480 & 11.88 & 17.3 \\
\hline
\end{tabular}

As can be seen in Figure 3, when crossflow velocity was $0.15 \mathrm{~m} / \mathrm{s}$, the TMP reached to the highest value of $36 \mathrm{kPa}$ after 5-hour filter run. With higher crossflow velocities, the increases of TMP were low. However, the increase of TMP value was not significant when the crossflow velocity was operated from $0.30 \mathrm{~m} / \mathrm{s}$ to further value of $0.60 \mathrm{~m} / \mathrm{s}$. This means the crossflow velocities of 0.30 $\mathrm{m} / \mathrm{s}$ or $0.45 \mathrm{~m} / \mathrm{s}$ were efficient to prevent physical fouling of the membrane for the given condition. The membrane fouling was found to be due to the biofouling of the biomass present in effluent from FMB.

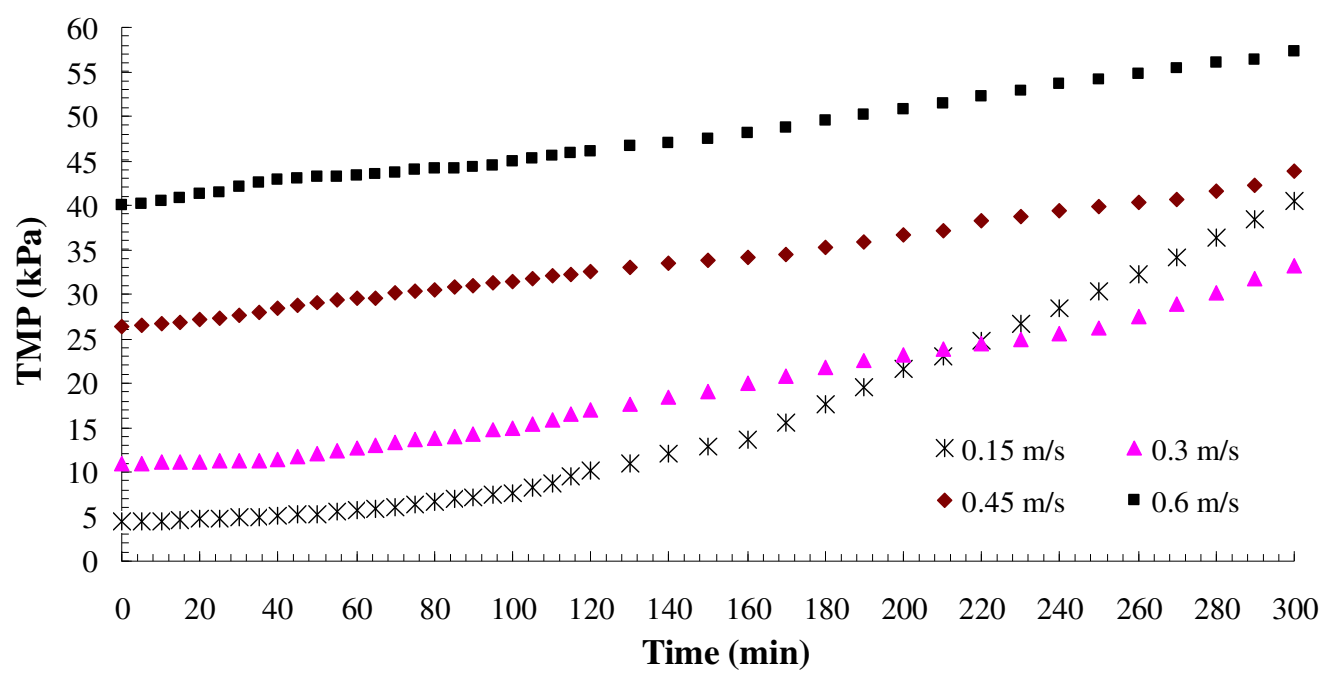

Figure 3 Effect of crossflow velocity on TMP increase of FMB-CFMF system (membrane pore size $=0.45 \mu \mathrm{m}$; filtration flux $=100 \mathrm{~L} / \mathrm{m}^{2} . \mathrm{h}$ ) 


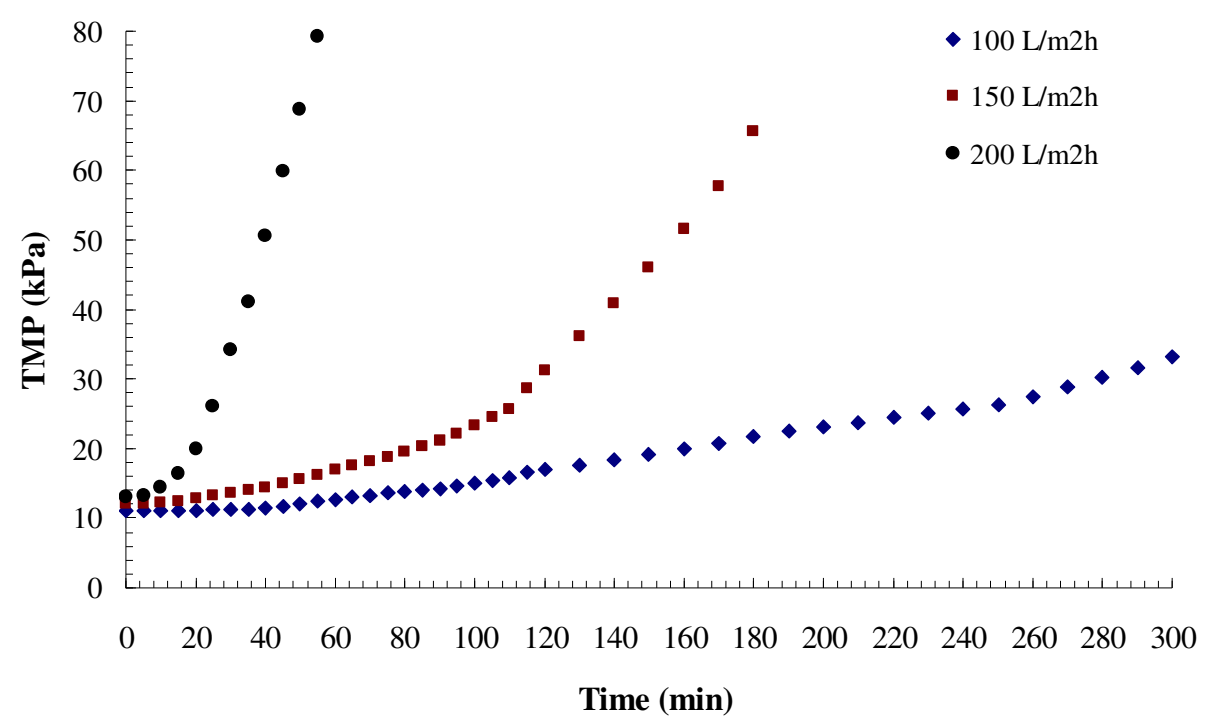

Figure 4 Effect of filtration flux on TMP increase of FMB-CFMF system (membrane pore size $=0.45 \mu \mathrm{m}$; crossflow velocity $=0.30 \mathrm{~m} / \mathrm{s}$ )

The effect of filtration flux on TMP increase was studied by varying the filtration flux in the range of $100-200 \mathrm{~L} / \mathrm{m}^{2} . \mathrm{h}$ (Figure 4). As expected, the lower filtration flux led to the lowest TMP development $(22.1 \mathrm{kPa})$ over the filtration time of 300 minutes. During first hour of operation, the TMP increase was marginal at filtration flux of $100 \mathrm{~L} / \mathrm{m}^{2} . \mathrm{h}$ suggesting that if periodic backwash frequency is adopted within one hour, the membrane reversible fouling can be restored. The average TOC removal efficiencies were $95.4 \%, 94.6 \%$ and $93.2 \%$ at the filtration fluxes of 100 $\mathrm{L} / \mathrm{m}^{2} . \mathrm{h}, 150 \mathrm{~L} / \mathrm{m}^{2} . \mathrm{L}$ and $200 \mathrm{~L} / \mathrm{m}^{2} . \mathrm{h}$ respectively over the filtration time of 300 minutes. In practice, the range of permeate flux for SMBR is 5 to $20 \mathrm{~L} / \mathrm{m}^{2} . \mathrm{h}$. Thus, the acclimatized FMB-SMBR system can be operated under sub-critical flux condition without significant fouling. FMB can be used as a pretreatment unit prior to SMBR, since it can reduce the loading of organic substances to membrane in MBR and minimize membrane fouling.

\section{Critical flux in SMBR and SMABR systems}

Critical flux experiments were carried out after 20-day operation of SMBR and SMABR systems at a constant permeate flux of $10 \mathrm{~L} / \mathrm{m}^{2} . h$ under the same hydraulic retention time (HRT) of 3.1 hours. The membrane was physically cleaned using backwash and the cake layer formed by activated sludge was brushed off before starting the critical flux experiment. Every 40 minutes flux-step, 1 minute backwash was provided at a backwash rate of $30 \mathrm{~L} / \mathrm{m}^{2} . h$ using membrane filtrate. The purpose of backwash was mainly to minimize the TMP increase due to reversible fouling during every experimental flux-step, which could lead to TMP development during the descending flux cycle comparing to ascending flux cycle. Figures 5 and 6 show the critical flux of SMBR and SMABR systems. According to the figures, both of the systems had the same critical flux value of $20-25 \mathrm{~L} / \mathrm{m}^{2} . \mathrm{h}$. However, the TMP value of the SMBR system was higher than that of the SMABR systems, which were 33 and $7.5 \mathrm{kPa}$ respectively at a filtration flux of $20 \mathrm{~L} / \mathrm{m}^{2} . \mathrm{h}$ (Table 3). This indicated that PAC can reduce membrane fouling. During the cycle test, it was observed that the TMP values obtained during the descending flux phase were greater than the corresponding flux values recorded during the ascending phase. Especially for SMABR system, the TMP values were nearly three times of the ascending phase values. For example, at the critical flux-step of $20 \mathrm{~L} / \mathrm{m}^{2} . \mathrm{h}$, 
TMPs were 7.5 and $21 \mathrm{kPa}$ for the ascending flux and descending flux phases, respectively. These observations indicated that SMABR system formed an initial irreversible fouling due to small PAC particles deposition when the filtration flux was higher than critical flux. The formation of some reversible fouling led to less TMP development of the SMBR system in the descending flux phase when compared to that of SMABR (Guo et al., 2007).

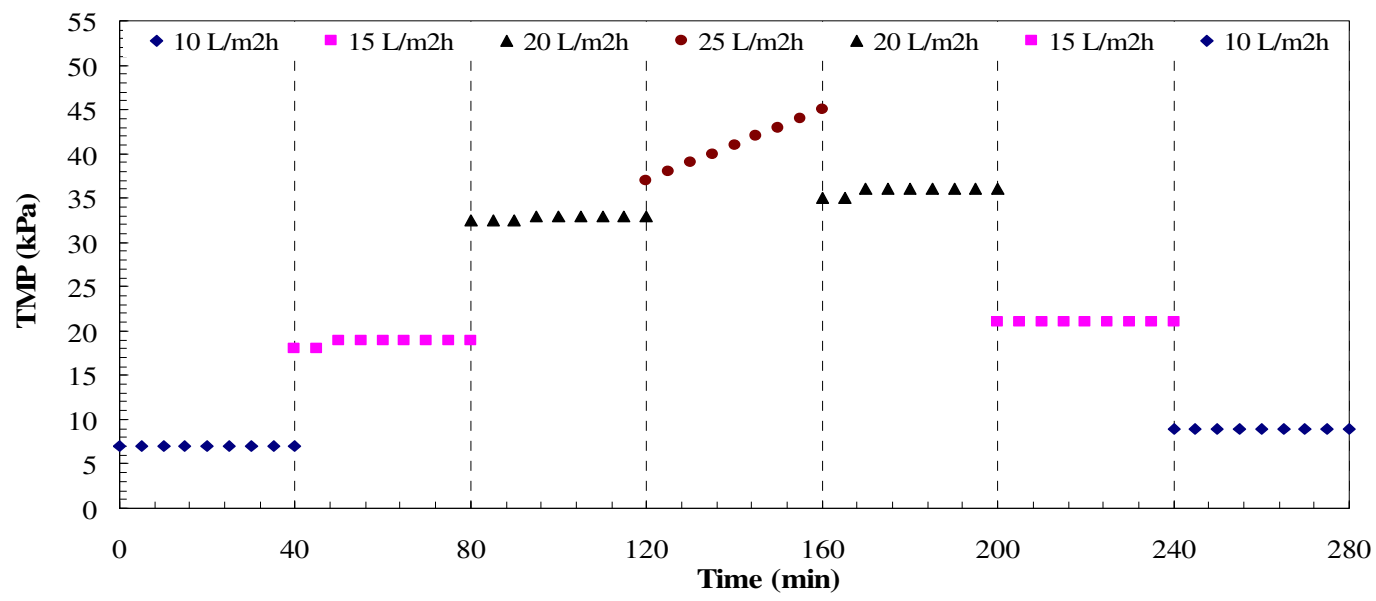

Figure 5 Constant filtration flux vs. TMP of SMBR system

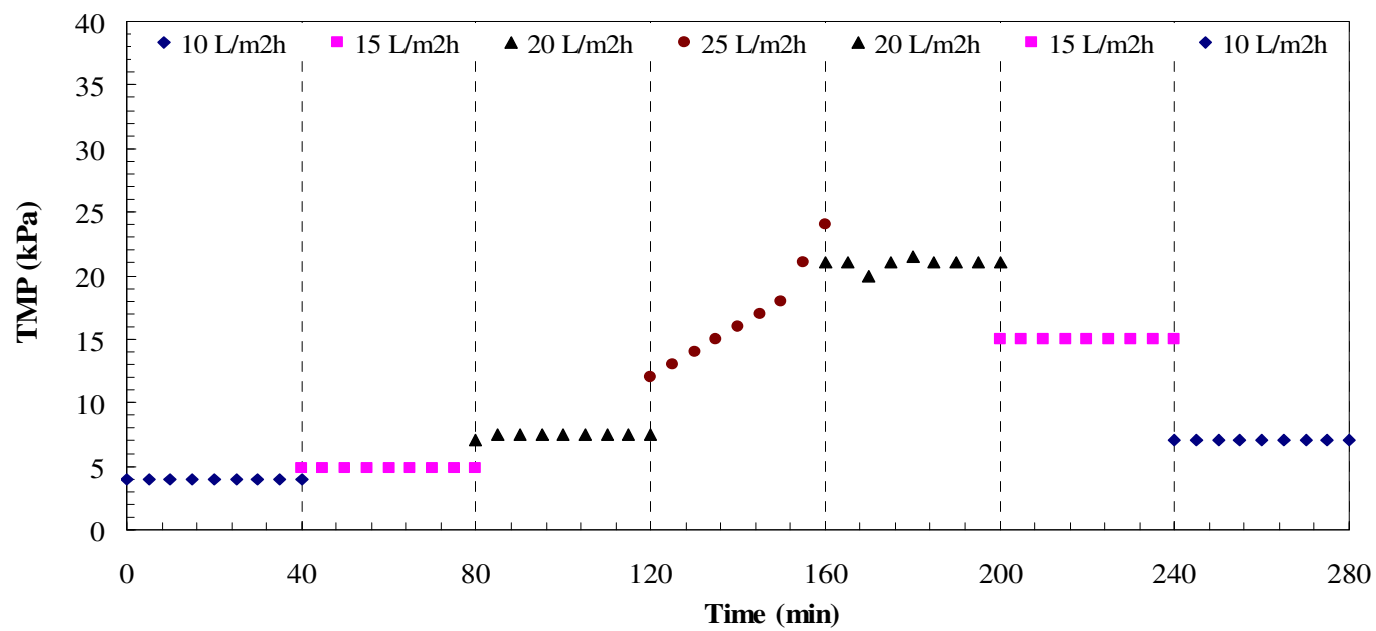

Figure 6 Constant filtration flux vs. TMP of SMABR system

Table 3 Sustainable flux of SMBR and SMABR systems

\begin{tabular}{|c|c|c|c|}
\hline System & $\begin{array}{c}\text { Sustainable flux } \\
\left(\mathrm{L} / \mathrm{m}^{2} . \mathrm{h}\right)\end{array}$ & $\begin{array}{c}\text { TMP value } \\
(\mathrm{kPa})\end{array}$ & TMP increase at $25 \mathrm{~L} / \mathrm{m}^{2} . \mathrm{h}(\mathrm{kPa})$ \\
\hline SMBR & 20 & 33 & 8 (from 37 to $45 \mathrm{kPa}$ during the 40 mins) \\
\hline SMABR & 20 & 7.5 & 12 (from 12 to $24 \mathrm{kPa}$ during the 40 mins) \\
\hline
\end{tabular}

\section{Critical flux in sponge-SMBR system}

Critical fluxes were measured in the sponge-SMBR system for the same initial mixed liquor suspended solids (MLSS) of $10 \mathrm{~g} / \mathrm{L}$ (Guo et al., 2007). An air flow rate of $9 \mathrm{~L} / \mathrm{min}$ was provided. Sponge volume fraction in the reactor was varied at $0 \%$ (no sponge), 10\% and $20 \%$ (Figure 7 and Table 4). Every flux step was of 1 hour duration. As can be seen in Figure 7, suspended sponge 
could significantly reduce the membrane fouling and enhance sustainable flux (two times increase with the sponge volume fraction of $10 \%$ ). A slight decline of sustainable flux was observed for $20 \%$ of sponge fraction. This is mainly due to the reduction of sponge cube mobility in the reactor. Sponge-SMBR system could achieve higher quality effluent with a total organic carbon removal efficiency of over $95 \%$ in all cases.

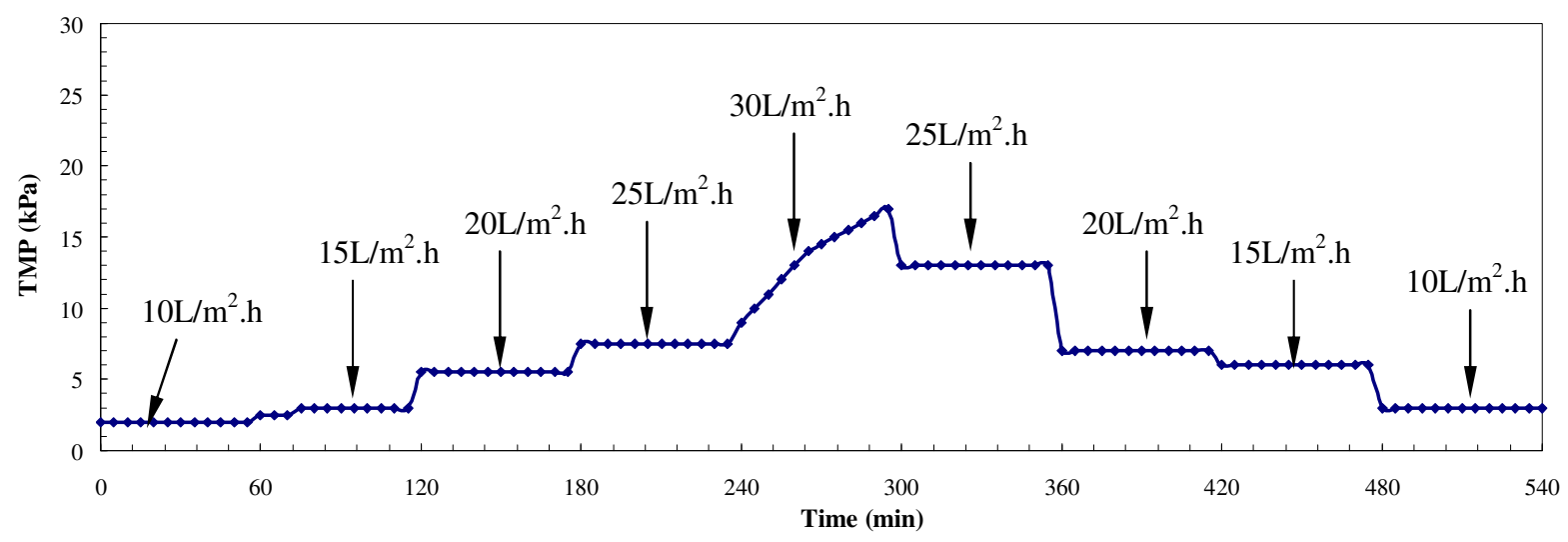

(a) SMBR only (Sponge volume $=0 \%$ )

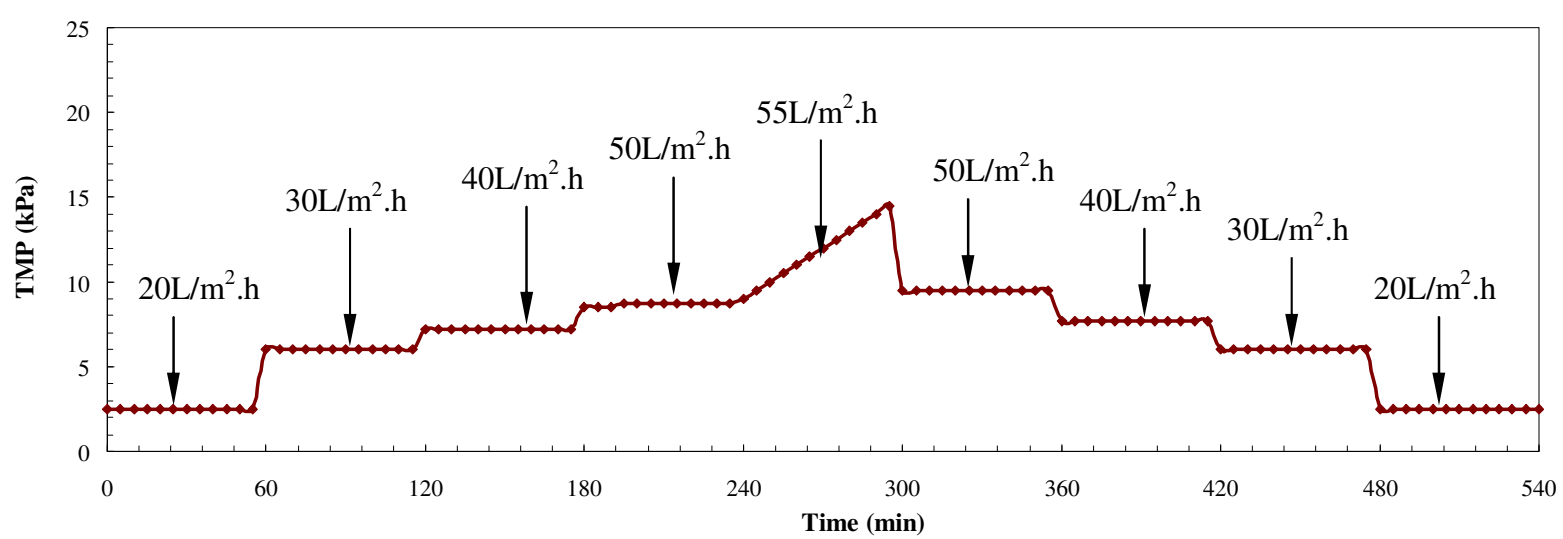

(b) sponge-SMBR (Sponge volume $=10 \%$ )

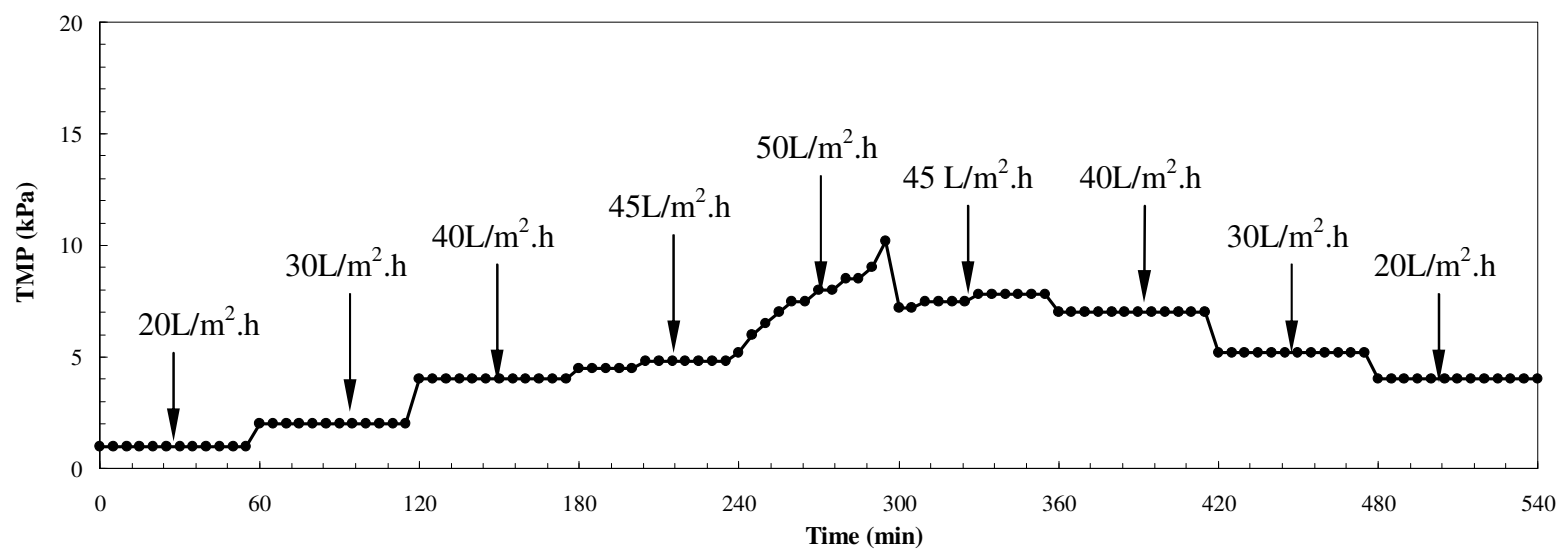

(c) sponge-SMBR (Sponge volume $=20 \%$ )

Figure 7 Constant filtration flux versus TMP of sponge-SMBR system 
Table 4 Critical flux and effluent quality in sponge-SMBR system

\begin{tabular}{|c|c|c|}
\hline Sponge volume $(\%)$ & Sustainable flux $\left(\mathrm{L} / \mathrm{m}^{2} . \mathrm{h}\right)$ & Effluent TOC $(\mathrm{mg} / \mathrm{L})$ \\
\hline 0 & 25 & $<6$ \\
\hline 10 & 50 & $<4$ \\
\hline 20 & 45 & $<5$ \\
\hline
\end{tabular}

\section{CONCLUSIONS}

FMB-CFMF showed a high TOC removal efficiency (over 90\%) and the TMP development was only $22.1 \mathrm{kPa}$ (during the 5 hours of operation) when FMB-CFMF was operated even at a high filtration flux of $100 \mathrm{~L} / \mathrm{m}^{2} . \mathrm{h}$. The acclimatized FMB can be used as a pretreatment unit prior to SMBR. It reduced the loading of organic substances to membrane in MBR and minimized membrane fouling when the FMB-CFMF system operates under sub-critical flux condition (filtration flux $<100 \mathrm{~L} / \mathrm{m}^{2}$.h; backwash frequency $<1$ hour).

Both SMBR and SMABR were found to be excellent in producing a high effluent quality. Both systems showed the same critical flux of $20 \mathrm{~L} / \mathrm{m}^{2}$.h with mixed liquor taken after 20 days of operation. However, the SMBR had higher TMP value to maintain the sustainable flux. Sponge addition in the SMBR could significantly improve the sustainable flux of the SMBR system. Sponge volume fraction of $10 \%$ with an air flow rate of $9 \mathrm{~L} / \mathrm{min}$ was found to give superior results.

\section{ACKNOWLEDGEMENT}

This research was funded by DEST International Science Linkages Competitive Grant and supported by EUROMBRA project.

\section{REFERENCES}

Fane, T. and Leslie, G. (2004). Membrane technology - The key to water reuse. Proceedings of IWA Specialty Conference, Water Environment-Membrane Technology (WEMT2004), Seoul, Korea, 7-10 June, 875-883.

Field, R. W., Wu, D., Howell, J. A. and Gupta, B.B. (1995). Critical flux concept for microfiltration fouling. Journal of Membrane Science, 100, 259-272.

Guo, W. S., Vigneswaran, S., Ngo, H. H., and Xing, W. (2007). Experimental investigation on acclimatized wastewater for membrane bioreactors. Desalination (In Press).

Guo, W. S., Vigneswaran, S., Ngo, H. H., Xing, W. and Goteti, P. (2007). Comparison of the performance of submerged membrane bioreactor (SMBR) and submerged membrane adsorption bioreactor (SMABR). Bioresource Technology (Submitted).

Guo, W. S., Ngo, H. H., Vigneswaran, S., Xing, W. (2007). A novel sponge-submerged membrane bioreactor for wastewater treatment and reuse. Biochemical Engineering Journal (to be submitted).

Kwon, D.Y. and Vigneswaran, S., Fane, A.G. and Ben Aim, R. (2000). Experimental determination of critical flux in cross-flow microfiltration. Separation and Purification Technology, 19, 169-181.

Lee, W., Kang, S., Shin, H., (2003). Sludge characteristics and their contribution to microfiltration in submerged membrane bioreactors. Journal of Membrane Science, 216, 217-227.

Stephenson, T., Judd, S. Jefferson, B. and Brindle, K. (2000). Membrane bioreactors for wastewater treatment. IWA Publishing, UK. 